\title{
Teaching Indigenous History and Heritage. Reviving the Past in the Present: Caribbean Experiences from the Dominican Republic and Dominica
}

\author{
Eldris Con Aguilar ${ }^{1}$, Arlene Álvarez ${ }^{2}$, Cozier Frederick ${ }^{3}$, Corinne L. Hofman ${ }^{1}$ \\ ${ }^{1}$ Faculty of Archaeology, Leiden University, Leiden, The Netherlands \\ ${ }^{2}$ Museo Arqueológico Regional Altos de Chavón, La Romana, Dominican Republic \\ ${ }^{3}$ Ministry of Kalinago Affairs, Roseau, Dominica \\ Email: e.o.con.aguilar@arch.leidenuniv.nl
}

How to cite this paper: Con Aguilar, E., Álvarez, A., Frederick, C., \& Hofman, C. L. (2017). Teaching Indigenous History and Heritage. Reviving the Past in the Present: Caribbean Experiences from the Dominican Republic and Dominica. Creative Education, 8, 333-346.

https://doi.org/10.4236/ce.2017.83026

Received: January 27, 2017

Accepted: March 7, 2017

Published: March 10, 2017

Copyright (c) 2017 by authors and Scientific Research Publishing Inc. This work is licensed under the Creative Commons Attribution International License (CC BY 4.0).

http://creativecommons.org/licenses/by/4.0/

\begin{abstract}
The Caribbean is well-known for its multi-ethnic and multi-cultural population, a consequence of its colonial past and Amerindian, European, African, and Asian influences. The role of this colonial heritage in defining contemporary Caribbean identities has been significant. Nevertheless, the indigenous peoples who inhabited the Caribbean in the past are not frequently referred to in modern-day Caribbean society. It is often believed that the indigenous inhabitants were wiped out soon after European arrival, yet recent archaeological and ethnographic studies have shown the survival of indigenous traditions and expressions in the present Caribbean. There is an indigenous resurgence movement among groups that self-identify with their Amerindian ancestors, and in Dominica the contemporary indigenous population has been officially recognized by the country's government. These important aspects of Caribbean history are highly relevant for the teaching of the national identity and cultural heritage, and need to be reflected in the school curricula of Social Studies across the region. This paper examines current educational practices regarding indigenous history and heritage in two Caribbean countries, each with a different historical background and development. The first study area lies in the northwest of the Dominican Republic, where Columbus encountered the so-called Taíno in 1492 and founded the first European settlements. The second study area is the Kalinago Territory in Dominica, home of the descendants of the Kalinago indigenous people. The teaching of indigenous history and heritage in the schools of these countries includes the pre-Columbian and colonization periods, reflecting the prevalence of traditional Eurocentered narratives in which the indigenous history ended with the Amerin-
\end{abstract}


dian "extinction" in past centuries. Contemporary issues receive little or no attention in the curricula.

\section{Keywords}

Indigenous Heritage, Curriculum, Caribbean History, Social Studies

\section{Placing Caribbean Indigenous History and Heritage in the School Curriculum}

The indigenous people of the Caribbean are part of the region's history. Nevertheless, most of the knowledge that has been disseminated about them is biased and responds to a Western point of view, starting with the European chroniclers who recorded what they encountered upon their arrival in the so-called "New World" (Forte, 2006; Wilson, 2007; Hofman et al., 2012). Furthermore, the region is still working towards the establishment of a strong educational system that can replace the dominance of European culture in the curriculum which has governed the region since the colonial period (Griffith, 1990). Certainly, today there is an increased interest in updating the educational resources in order to include recent scientific advances in the fields of archaeology and anthropology that are helping to shed new light on what can be called a forgotten chapter in Caribbean history (Hofman et al., 2017) ${ }^{1}$.

In Caribbean textbooks of Social Studies and History this topic is often included in general terms such as "The first people", "The people of origin", or "The first inhabitants" at the start of the course in the first grades of primary school. Even so, the coverage of the pre-Columbian period in these educational resources requires updating and has to be expanded. The main sources of information to access this chapter of Caribbean history ${ }^{2}$ still are the European chronicles. This has to do with the inherited Eurocentric perception that the starting point of Caribbean history is 1492, i.e. the arrival of the Europeans (Hofman et al., 2017). For instance, Reid (2009) reminds us that history is not based only on written records, but comprises all human actions, including those recorded orally and reflected exclusively in the archaeological record (p. 1).

These resources lack sufficient accuracy as they often portray an image of the indigenous peoples as being inferior to the European colonists (Ulloa \& Várcarcel, 2016). Archaeological findings in the Caribbean region have become valuable sources of information to learn about this chapter of its history before the

${ }^{1}$ Eldris Con Aguilar had the opportunity to interview representatives of the Ministries of Education in the Dominican Republic and Dominica. They expressed their interest to include information about the contributions of recent archaeological findings or heritage studies in the contents of the Social Studies lessons whenever this is of benefit to the schoolchildren.

${ }^{2}$ Often influential scholars and authors of school textbooks such as Honychurch (1995a) for the Eastern Caribbean and Veloz Maggiolo (1997) for the Dominican Republic use the term "prehistory" to refer to the period before the European encounters, also known as the pre-Columbian era. The information available on the first inhabitants is then studied as the Prehistory of the Caribbean. 
European encounters. The cultural material remains to have served to shed light on the first inhabitants (Honychurch 1995a; Serna, 2010). In addition, oral traditions can also serve to give an account of the indigenous peoples of the Caribbean (Pesoutova \& Hofman, 2016).

These local stories and narratives that have survived across time can serve to inform about the indigenous peoples through non-formal educational activities, but this requires strengthening of the relations between local communities and schools. In many countries heritage education is not yet a separate subject area in the school curriculum. Elements of indigenous history and heritage can be found in the subjects of Social Studies and History. Teachers organize many practices such as visits to historic sites and museums or working with artifacts that can be considered as "heritage education" (Grever \& van Boxtel, 2011: p. 9). Similarly, in Caribbean schools indigenous history and heritage is not taught as a separate subject, but related contents are embedded in the curriculum subject area of Social Studies. These contents include specific aspects of the indigenous lifeways in the past, traditional culture and other perspectives of Caribbean history.

The multi-diversity of the Caribbean is also reflected in its educational systems. When searching for indigenous history and heritage in the curricula, it becomes apparent that it is primarily incorporated in the subject area of Social Studies (termed "Social Science" in some countries). Social Studies (or "Estudios Sociales" in Spanish) can be found in the curricula of most Caribbean countries". It is related to citizenship education. An important objective of Social Studies is to provide young people with the knowledge and competences to become active citizens in their society and to behave accordingly. In the Caribbean society, debates have focused on what has been observed as deviant behavior among the youth and in response to this governments have taken to implement citizenship education (Howe \& Marshal, 1999).

However, the course goals vary depending on the local and regional contexts. For example, in Spanish-speaking Caribbean countries like the Dominican Republic, educational policies are different from those in neighboring Anglophone countries.

Considering their diverse educational backgrounds, in the following sections the representation of indigenous history and heritage in the Social Studies (Social Science) curriculum in a Spanish and an English-speaking country will be explored in order to provide an accurate overview of their particular educational contexts, goals and practices.

\section{The "Taíno" Influence in Social Science Lessons in the Dominican Republic}

Since 2008 the "Ten Year Education Plan for 2008-2018" ("Plan Decenal de

${ }^{3}$ In the French Antilles the subject areas of History and Geography are taught together in the same course in primary and secondary schools; the name Social Studies is not used. In the Dutch Caribbean, depending on the political status of the individual islands, schools will follow the guidelines of the Ministry of Education of the government of The Netherlands where the attainment target is referred to as Social and Environmental Studies. 
Educación 2008-2018") has been the policy guidance for the implementation and development of primary and secondary education in the Dominican Republic. The term Social Science ("Ciencias Sociales") is used in the national curriculum. This curricular reform aims at the introduction of a competency-based educational model capable of promoting a more cohesive formation of the student. These competencies will serve as interdisciplinary connectors between the different subject areas of the curriculum. The primary competencies of the new curriculum are shown in Table 1.

The "Etica y Ciudadana" competency ranges first on the list. This translates to "Ethics and Citizenship", the competency which can be considered as the cornerstone of all fundamental competencies in the Social Science curriculum for both primary and secondary school levels. The curriculum contents for Social Science in the new curriculum includes General History and Dominican History, Culture, and Geography, starting from the $2^{\text {nd }}$ grade of primary school, thus covering the teaching of those historical events, including the lifeways of the first inhabitants, that are essential for the appreciation of Dominican culture, heritage and identity.

National narratives of Taíno ${ }^{4}$ indigeneity gained particular prominence in the Dominican Republic in the literature produced by the "indigenistas dominicanos" who contributed to the construction of a romantic idea of the Amerindians, depicting them as a national symbol (Pesoutova, 2015; Ricourt, 2016). Moreover, during the dictatorial rule of Rafael Trujillo from 1930 to 1961 indigeneity was considered as an element of national pride and distinction in Dominican society (Priego, 1967; Mateo, 2004). In fact, today's Social Science curriculum preserves the Amerindian heritage as an essential component in defining the Dominican identity. But it also seeks to value those aspects of the Spanish and African cultures that have contributed to shape contemporary Dominican culture. As a re-

Table 1. Fundamental Competencies for primary and secondary school levels in the Dominican Republic.

\begin{tabular}{cc}
\hline Competencies (Original in Spanish) ${ }^{\mathrm{a}}$ & Competencies (Translation) \\
\hline Ética y Ciudadana & Ethics and Citizenship \\
Comunicativa & Communication \\
Pensamiento Lógico, Creativo y Crítico & Logical, Creative and Critical thinking \\
Resolución de Problemas & Problem-solving \\
Científica y Tecnológica & Technological and Scientific \\
Ambiental y de Salud & Health and Environmental \\
Desarrollo Personal y Espiritual & Personal and Spiritual Development
\end{tabular}

${ }^{a}$ Adapted from the Curricular Design Ministerio de Educación de la República Dominicana (MINERD) 2016a; 2016b, 2016c.

${ }^{4}$ Taíno is a term used by the local population of the Dominican Republic to refer to their Amerindian ancestors. Its indiscriminate use has led to an understanding of the Taíno being a homogenous group of people; this thesis differs from the most recent archaeological findings in the region. For an extensive discussion of this topic, see Curet (2014). 
sult, there is a more inclusive approach to teaching about cultural identity which makes it interesting for educational research: to explore to what extent the newly revised objectives of the Social Science curriculum contribute to the education of thoughtful citizens who are prepared to live in a multi-ethnic society.

But the information that the school textbooks reflect about the indigenous history and heritage is still based on the European perspective recorded by the chroniclers after the Spanish arrival in the New World (Hofman et al., 2012; Pesoutova, 2015). For instance, textbooks place a lot of importance on the organization of the island of Hispaniola in five cacicazgos ("chiefdoms"). This model of five cacicazgos derives from a map drawn by the Jesuit priest François-Xavier de Charlevoix (1731), based on the historic records left by early-colonial chroniclers such as Las Casas, Oviedo and Martir de Anglería (Anghiera, 1989; Las Casas 1987; Rodríguez López-Vázquez \& Rodríguez López-Abadía, 2016). School textbooks also give weight to the notion that the indigenous inhabitants of Hispaniola, the Taíno, were a single homogeneous and unified group of Amerindians without exploring in depth and giving consideration that there were regional differences in language and culture among them (Reid, 2009; Keegan \& Hofman, 2017). It is also evident that the prevalence of the use of the term Taíno responds to a dichotomy inherited from colonial times, that between the Arawak and Carib Amerindians (Hofman et al., 2008; Reid, 2009; Curet, 2014; Pesoutova \& Hofman, 2016; Keegan \& Hofman, 2017). Besides, there is an emphasis on the routes of migration taken by the Amerindians from the northeast coast of South America moving through the corridor of the Lesser Antilles to the Greater Antilles (Veloz Maggiolo, 1997; Wilson, 1997).

Most recently, under the auspices of the ERC-Synergy NEXUS1492 project, archaeological research in the Dominican Republic has focused on exploring the world of the indigenous peoples by reconstructing their life ways and death ways from the remains of material culture (Ulloa \& Herrera Malatesta, 2015; Sonnemann et al., 2016; Hofman et al., 2016; Hofman et al., 2017). For instance, Herrera Malatesta (2016) is studying how early cartography is a representation of the understanding and use of the territory by the Spaniards. Within this context, his research is evaluating the map of the five cacicazgos produced by Charlevoix and how twentieth-century archaeologists have been using it to reproduce and legitimize a model which is not necessarily accurate and that perhaps is obscuring more information than highlighting $i^{5}$. All the information obtained will certainly require some time before it can be included in officially authorized textbooks considering that the textbooks for the new reform have already been printed.

On the other hand, the museum community of the Dominican Republic has been quite active in offering opportunities for non-formal education to local schools so that both teachers and students can learn from the archaeological remains left by the indigenous peoples of Hispaniola. During one of Con Aguilar's

${ }^{5}$ Herrera Malatesta and Con Aguilar are collaboratively studying the possible impacts that the new understanding of the cacicazgos in Hispaniola may have in the teaching of the past indigenous lifeways. Results are expected to be available in 2017-2018. 
field visits to the Dominican Republic in 2014-2015 she was able to visit different museums with Amerindian archaeological collections. From the interviews with staff personnel it was noticed that besides school visits these institutions also provide various other outreach activities that are of interest to the entire school community such as seminars, public lectures and temporary exhibitions. Moreover, they offer training courses for teachers and also educational resources (Con Aguilar, 2016: p. 32). Non-formal education activities and resources offered by museums and other cultural centers serve as a bridge between the local schools and the recent advances in research about the Amerindian heritage of the islands.

The interviews showed that the teachers are interested to learn more about the first inhabitants of the island. For the teachers it proves to be important to have knowledge of heritage resources, even though these are located outside the school grounds because they provide them with opportunities to engage their students in more interactive "hands-on" learning about the indigenous peoples and their heritage (Figure 1).

Recent archaeological findings are contributing to shed light on the lifeways and death ways of the first inhabitants (Ulloa Hung, 2014; Hofman \& Hoogland, 2015; Hofman et al., 2016; Hofman et al., 2017). Many of their traditions and beliefs are still alive in religious and cultural expressions in Dominican present-day society (Serna Moreno, 2010; Pesoutova \& Hofman, 2016). However, ways have to be found to incorporate these new developments in the curriculum and to make them accessible to teachers and students. Clearly, the incorporation of recent scientific advances that can contribute to enrich the knowledge about the Amerindians will require an active dialogue between specialists, teachers and the rest of the school community.

The case study about Dominica shows that the connections between past and present are perceived differently here because of the presence of descendants of the indigenous inhabitants of the island in today's society. Therefore, it raises questions of different dimensions about the curriculum of Social Studies.

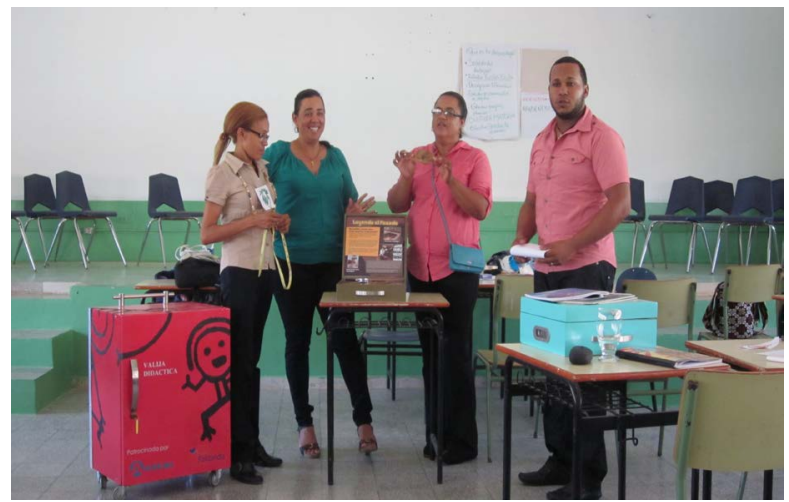

Figure 1. Primary school teachers participating in a workshop organized by Con Aguilar and Álvarez in the local school district of Monte Cristi, Dominican Republic, in 2015. The picture shows the teachers experiencing with the hands-on activities of " $L a$ valija didáctica" ("The didactic suitcase") about the indigenous peoples of the Dominican Republic. This is an educational resource, offered by the Museo Arqueológico Regional Altos de Chavón. (Photo taken by Con Aguilar with permission of the teachers.) 


\section{Dominica: The Presence of Kalinago Indigenous Knowledge and Practices in the Curriculum}

The second study area is located in Dominica, one of the few countries in the Caribbean region with an indigenous population, the Kalinago. The indigenous name for Dominica is "Waitikabuili" (“Tall is her body”). The Kalinago are officially recognized in Dominican legislation and around 3000 of them live in the Kalinago Territory in the north-central section of the island; the land is communally held and the Territory has a Kalinago Council for local government.

Dominica was encountered by Columbus and his crew during the Admiral's second voyage of 1493. Likewise the situation in the Dominican Republic, most of what is known of the Kalinago or the so-called "Island Carib" can be found in the historic records of the early European chroniclers (Honychurch, 1995b: p. 21; Hofman \& Hoogland, 2012; Allaire 2013; Keegan \& Hofman, 2017). Kalinago words are still preserved today thanks to the descriptions by Father Breton in his Carib-French and French-Carib dictionaries (Breton 1665-1666).

Because of the presence of the Kalinago in the island today, there is also knowledge that has survived and is being transmitted through oral stories and traditions. The Kalinago heritage has been incorporated in the main national festivities and is celebrated in yearly events like the Kalinago Week in September, Independence Week and Carnival. Community participation in the Territory is very active: there are several non-governmental organizations with a cultural character such as the Karina Cultural Group.

Politically, at the national government level, there is a Ministry of Kalinago Affairs and a Kalinago Member of Parliament. Concerning education at the national level, representatives of the Kalinago people consider that there is still room for more information about their cultural heritage and history that can be incorporated in the school curriculum. Therefore, in 2003 some members of the community wanted to contribute actively to the school community, and designed a Kalinago curriculum to be discussed with the national education authorities. The contents of this curriculum are related to inherited Kalinago indigenous knowledge. This document has yet to be taken to the correspondent authorities, as a result of which this is a project in hold.

This paper focuses on exploring how the indigenous history and heritage of the Kalinago people is currently represented in the curriculum for primary schools. In this sense, it is important to consider that Dominica is a member state of the Organization of Eastern Caribbean States (OECS). As such it subscribes to regional efforts to harmonize the educational development across the associated states, for example, the OECS Education Sector Strategy for 20122021 (OECS, 2012). This agenda looks at facilitating the mobility of students in the region by offering an educational program that meets the regional and international demands of globalization and technological advances. In this way regional policies influence the curriculum design at the local country level. In fact, in 2006 a teacher's guide for primary school Social Studies was published by the OECS Education Reform Unit with the purpose of enhancing the teachers' ex- 
pertise in the Social Studies classroom and to offer them suggestions to organize participatory activities. This document was generated and informed by the existing content and objectives in the national Social Studies curriculum across the individual OECS countries, intending to provide a common set of learning standards relevant for the Social Studies classrooms across the OECS (adapted from the OECS Education Reform Unit 2006: p. 9). The curriculum for secondary schools is guided by the Caribbean Examination Council (CXC), a regional examining body for the English-speaking Caribbean countries.

Consequently, with a primary school curriculum designed at local level, there is room to discuss content and practices that can enhance the learning experiences offered by the Social Science course. In Dominica content related to its indigenous history and heritage is found in Social Science one of the seven core subject areas of the primary school curriculum. The primary school Social Science program includes four subject strands, from Grade K to Grade 6: Civic Ideas and Practice; Location, Places and People; Resources; Social issues and Change. Consequently, the teaching of the indigenous history and heritage is considered part of the citizenship education of Caribbean children and it aims to contribute to the formation of their Caribbean identity (Commonwealth of Dominica, Ministry of Education, 2015).

But these attempts at regional harmonization of the curriculum have also been accompanied by less desirable effects. In particular, educational materials for Social Studies are produced focusing on content that is relevant for the Eastern Caribbean region and for the formation of a Caribbean identity. This way, limited room is available to incorporate local indigenous knowledge. This has contributed to the maintenance of historical perspectives in school textbooks that not necessarily correspond to contemporary archaeological and anthropological studies about the region's pre-Columbian period. Regional textbooks for primary schools still carry the traditional vision of the Amerindians in the Caribbean as consisting of two groups of people: the Arawak and the Carib, who arrived from northern South America. But how do teachers make use of these resources in their Social Studies classrooms?

In 2015 and 2016 Con Aguilar had the opportunity to visit the Kalinago Territory twice and interview teachers of the local primary schools. In these interviews one of the main concerns expressed by the teachers referred to the textbooks and other educational resources available to them for giving lessons in indigenous history and heritage. Since these were produced for the Eastern Caribbean countries, they did not have enough local content on the Kalinago. They did not include any mention of the knowledge possessed by their ancestors and the practices that may have survived (modified or not) across the historical divide. Of the series of Social Studies textbooks recommended by Dominica's Ministry of Education and Human Resources for primary schools only one is produced locally: "Caribbean Social Studies, Book 4 (Dominica)" by Jno-Baptiste (1995). The rest are meant for the wider Eastern Caribbean school audience. However, the Chief Education Officer expressed that there are books that have 
been written in the Kalinago Territory about the culture and heritage of the Amerindians of which it is made sure that they are available and are being read by the children (Interview with the Chief Education Officer, Dominica, January 2016). In this vein, teachers often refer to how they make use of other books and resources available to them to be able to complement the topic of the "Indigenous People" with additional information. Since often these resources were not specifically designed for teaching, they had to re-organize their content in order to bring it to an adequate level for the age groups of their classes.

As in the Dominican Republic, most of the activities which enable the school community to obtain a larger knowledge of the indigenous history and heritage are undertaken by local institutions. In the case of Dominica, there are community members in the Kalinago Territory who are actively involved with the local schools. For example, the Kalinago Cultural Officer, Mr. Prosper Paris, is often invited as a resource person to give talks to students about the history and heritage of the Kalinago people. Then there are the members of the Karina Cultural Group who are also invited to participate in school activities and share their traditional dances with the students.

In 2016 Frederick and Con Aguilar organized a participatory workshop together with members of the Karina Cultural Group and the Kalinago Council. The role of the teachers was explored in this activity as well as the methods and practices they apply in their classrooms in order to introduce the topic of indigenous history and heritage. It was observed how teachers found ways to make educational use of numbers spelled in the Kalinago language, teaching young children the numbers from 1 to 10 in mathematics lessons (Figure 2).

In addition, it was noted how the medical use of herbs and plants, being an important part of the indigenous knowledge, was a topic of interest for the teachers. For example, one of the schools participating in the workshop, the Atkinson Primary School, organized activities in which schoolchildren had to make a herbarium by collecting plants of local use and writing down information on them from interviewing their relatives and friends in the community (Figure 3).

Frederick and Con Aguilar also visited primary schools outside the Kalinago Territory, notably in and near Roseau, the island's capital, in the southwestern part of the island and had interviews with their teachers in January-February 2016. Teachers from these schools showed interest in learning more about the lifeways of the Kalinago in order to enable their students to gain a better knowledge and closer experience of the Kalinago. In this respect they indicated that a good opportunity for students from towns such as Roseau and Soufriere to get to know more about the Kalinago, past and present, was to visit the Barana Autê, the Kalinago model village in the Territory.

Local knowledge about the indigenous inhabitants of Dominica is mainly informed by the narratives that have survived across time, reinforced with the presence of the Kalinago people in the island. But in comparison with the Greater Antilles (Dominican Republic, Puerto Rico, Jamaica, Haiti, Cuba), not as 


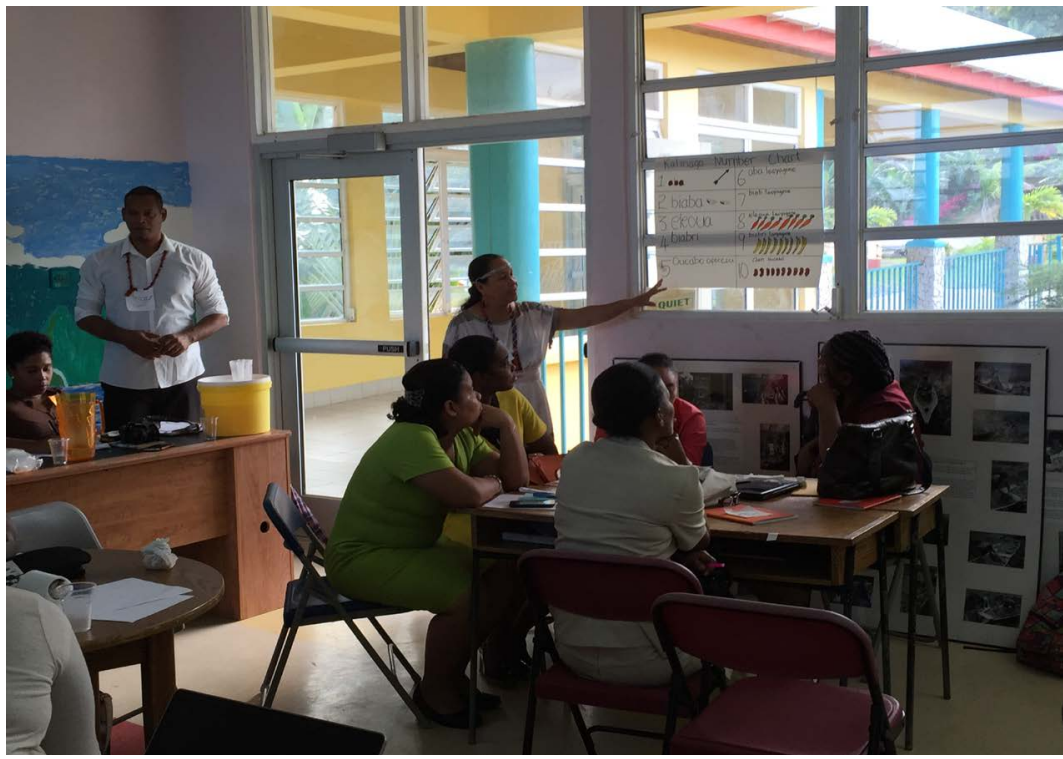

Figure 2. Mrs. Miranda Langlais, Karina Cultural Leader, explaining to teachers the numbers as spelled in the Kalinago language, while showing them an activity to incorporate this in order to teach counting [arithmetic] to small children. (Photo by Con Aguilar.)
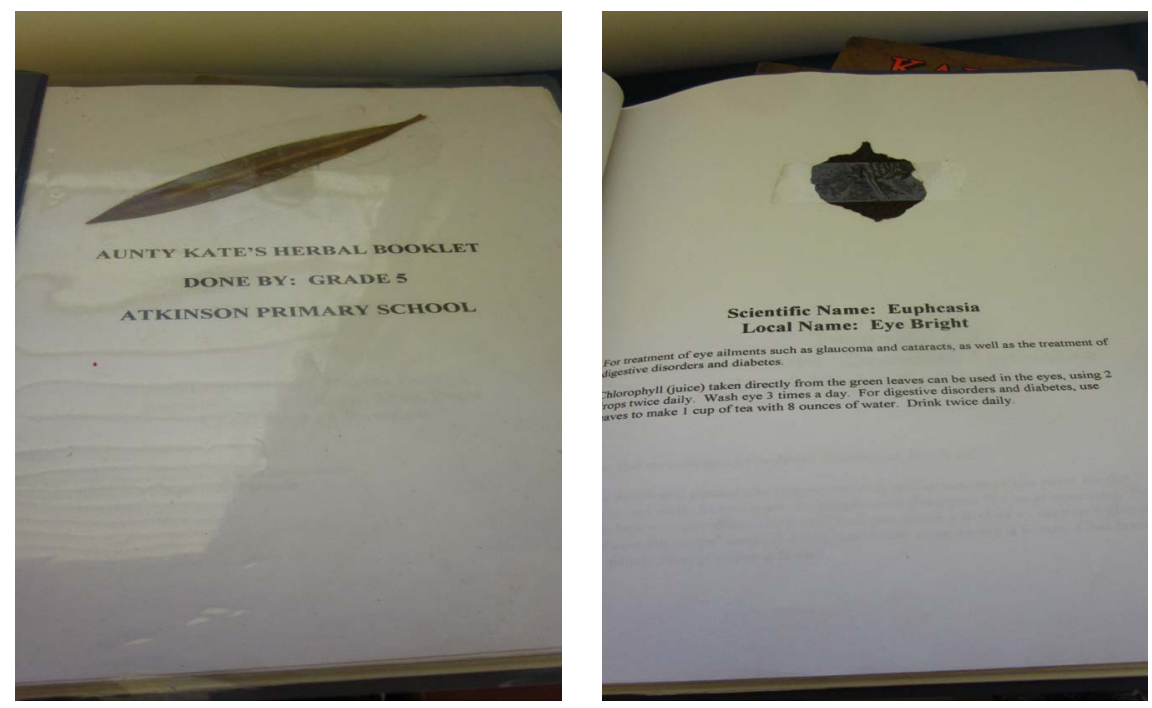

Figure 3. Herbal booklet in the library of the Atkinson Primary School, Dominica. (Photo taken by the author and reproduced with permission of the Atkinson Primary School.)

much archaeological research in former Amerindian settings has taken place here. However, archaeological studies have been made in the area of the Lesser Antilles (Bérard, 2013; Grunberg, 2015). Therefore, what is best known are the indigenous traditions and cultural production, still existing among the indigenous people today.

\section{Conclusions: Re-Defining the Concept of Indigenous Heritage: Caribbean Perspectives}

The notion of indigenous heritage in the Caribbean is not an unfamiliar idea to 
the local people. In the two countries where this study was conducted, school teachers think of indigenous heritage as teaching about the knowledge of the ancestors; these distinct educational settings differ according to their relation with the past. Because of their varied historical background, Caribbean societies are very diverse, and this heterogeneity is also reflected in today's multi-ethnic configuration. One can find societies in which the indigenous past has survived the effects of colonialism and has become a typical component of the nation building narratives. This study looked at how these narratives are represented in the Social Studies (Social Science) school curriculum.

It was observed how the national narratives of identity influence the way the indigenous history and heritage is taught in the case of the Dominican Republic while in Dominica a regional narrative of Caribbean identity prevails which is informed by regional associations such as the OECS. And identity has been a topic of political interest across the region due to recent historical circumstances as, for example, the obtaining of independence by many English-speaking nations in the second half of the twentieth century. This is reflected in the syllabus of Social Studies or Social Sciences where the teaching of indigenous heritage has become integrated in themes that also deal with cultural identity.

In the Dominican Republic, the indigenous heritage has been an essential component of the national identity discourse that gained more significance because of the historical disputes with Haiti (Ricourt 2016). However, what first seemed to be a nostalgic idea of the past has begun to gain more interest from the local population. Today, there are often persons who proclaim themselves as direct descendants of the Taíno. However, these discussions are not yet included in the curriculum. And these recent developments take place in an atmosphere in which the prevailing line of thought is still that of the "disappearance" or "extinction" of the indigenous population (and therefore also their history and heritage) after the arrival of the Europeans. Meanwhile, in Dominica the contemporary presence of the Kalinago indigenous people places different challenges on the society and its education system. There is for example the need to raise awareness among the local majority population of non-Kalinago about the contributions of the Kalinago to Dominica history and today's society.

In both case studies it was observed that non-formal educational institutions such as museums and non-governmental organizations can play an important role in providing the school community with activities and resources that contribute to enrich the experiences of students when learning about the indigenous peoples of the Caribbean. However, most of the efforts undertaken by these external stakeholders still occur on an irregular basis. The challenge towards the future is to incorporate these experiences into the regular school programs across the region. From the interactions with teachers and other education stakeholders during the field visits, it became evident that one of the ways to achieve this was through teachers' training and professional development.

Some museums in the Dominican Republic already offer short training courses to in-service teachers. However, there is as yet no formalized partnership 
between the museums and the educational authorities. In Dominica the initiatives of the Kalinago community have focused mainly on assisting teachers during some activities for the school children. Providing teachers with the content knowledge and pedagogical methods certainly will enhance both the teaching and the learning experiences about the indigenous peoples of the Caribbean. This can be achieved by offering quality continuous professional development to in-service teachers and by ensuring the participation of museums and other indigenous heritage institutions on a long-term sustainable basis.

\section{Acknowledgements}

The research on which this paper is based forms part of the NEXUS1492 project conducted under the direction of Prof. Dr. C.L. Hofman and has received funding from the European Research Council under the European Union's Seventh Framework Programme (FP7/2007-2013)/ERC grant agreement no. 319209.

In the Dominican Republic this study has been possible by the valuable cooperation of the Museo Arqueológico Regional Altos de Chavón. Workshops and interviews in the provinces of Valverde and Monte Cristi were made possible due to the effective assistance of the District Educational authorities and school communities. In Dominica, our thanks go to the Chief Education Officer of the Ministry of Education and Human Resource Development; the Ministry of Kalinago Affairs; Mr. Prosper Paris, Cultural Officer of the Kalinago Territory; Mrs. Miranda Langlais and Mr. Gerard Langlais of the Karina Cultural Group; and members of the Kalinago community. Special thanks and appreciation are due to our teacher colleagues who participated in the workshops, interviews and all other activities. Finally, Arie Boomert is thanked for editing the text.

\section{References}

Allaire, L. (2013). Ethnohistory of the Caribs. In W. Keegan, C. L., Hofman, \& R. Rodríguez Ramos (Eds.), The Oxford Handbook of Caribbean Archaeology (pp. 97-108). New York: Oxford University Press.

Anghiera, P. M. (1989). Décadas del Nuevo Mundo. Santo Domingo,: Sociedad Dominicana de Bibliófilos.

Bérard, B. (2013). Martinique, terre amérindienne: Une approche pluridisciplinaire. Leiden: Sidestone Press.

Commonwealth of Dominica, Ministry of Education and Human Resource Development (2015). Programmes of Study for Grade K to 6. http://education.gov.dm/departments/curriculum-unit

Con Aguilar, E. (2016). Tras la pista de nuestros primeros pobladores: Investigaciones arqueológicas en el norte de la Española. Memorias de Quisqueya, 8, 27-33.

Curet, L. A. (2014). The Taíno: Phenomena, Concepts, and Terms. Ethnohistory, 61, 467-495. https://doi.org/10.1215/00141801-2681759

Forte, M. (2006). Indigenous Resurgence in the Contemporary Caribbean: Amerindian Survival and Revival. New York, NY: Peter Lang.

Grever, M., \& Van Boxtel, C. (2011). Introduction Reflections on Heritage as an Educational Resource. In C. van Boxtel, S. Klein, \& E. Snoep (Eds.), Heritage Education Challenges in Dealing with the Past (pp. 9-13). Amsterdam: Erfgoed Nederland. 
Griffith, A. (1990). Social Studies for Nation Building. A View from Developing Society. ProQuest, 81, 161-165.

Grunberg, B. (2015). À la recherche du Caraibe perdu. Les populations amérin-diennes des Petites Antilles de l'époque précolombienne à la période coloniale. Paris: L'Harmattan.

Herrera Malatesta, E. (2016). Contested Taskscapes: On Perceptions of the Environment in the Age of Colonial Encounter. Sweden: Uppsala University.

Hofman, C. L., \& Hoogland, M. L. P. (2012). Caribbean Encounters: Rescue Excavations at the Early Colonial Island Carib Site of Argyle, St. Vincent. Analecta Praehistorica Leidensia, 43, 63-76.

Hofman, C. L., \& Hoogland, M. L. P. (2015). Beautiful Tropical Islands in the Caribbean Sea: Human Responses to Floods and Droughts and the Indigenous Archaeological Heritage of the Caribbean. In W. J. H. Willems, \& H. Schaik (Eds.), Water and Heritage: Material, Conceptual and Spiritual Connections (pp. 99-119). Leiden: Sidestone Press.

Hofman, C. L., \& Hoogland, M. L. P. (2016). Connecting Stakeholders: Collaborative Preventive Archaeology Projects at Sites Affected by Natural and/or Human Impacts. Caribbean Connections, 5, 1-31.

Hofman, C. L., Bright, A. J., Keegan, W. F., \& Hoogland, M. L. P. (2008). Attractive Ideas, Desirable Goods: Examining the Late Ceramic Age Relationships between Greater and Lesser Antillean Societies. Journal of Island and Coastal Archaeology, 3, 17-34.

Hofman, C. L., Davies, R. G., Brandes, U., \& Willems, W. J. H. (2012). ERC Synergy Grant 2012, Research Proposal. NEXUS1492: New World Encounters in a Globalising World. Leiden: Leiden University.

Hofman, C. L., Ulloa Hung, J., Herrera Malatesta, E., Jean, S. J., \& Hoogland, M. L. P. (2017). Indigenous Caribbean Perspectives: Archaeologies and Legacies of the First Colonized Region in the New World.

Honychurch, L. (1995a). The Caribbean People. Book 3, Cheltenham: Thomas Nelson \& Sons.

Honychurch, L. (1995b). The Dominica Story: A History of the Island. London: MacMillan.

Howe, G. D., \& Marshal, D. D. (1999). Citizenship Education, Democracy and Global Shifts: Re-Thinking Caribbean Social Studies. Kingston: UNESCO.

Jno-Baptiste, M. (1995). Caribbean Social Studies, Book 4-Dominica. Macmillan Caribbean, London.

Keegan, W. F., \& Hofman, C. L. (2017). The Caribbean before Columbus. Oxford: Oxford University Press. https://doi.org/10.1093/acprof:oso/9780190605247.001.0001

Las Casas, B. (1987). Historia de las Indias. Santo Domingo: Sociedad Dominicana de Bibliófilos.

Mateo, L. A. (2004). Mito y Cultura en la Era de Trujillo. Santo Domingo: Manatí.

Ministerio de Educación de la República Dominicana (MINERD) (2016a). Diseño Curricular-Nivel Primario-Primer Ciclo (1er., 2do. y 3ro.). Santo Domingo: Ministerio de Educación de la República Dominicana.

http://www.educando.edu.do/portal/wp-content/uploads/2016/07/NIVEL-PRIMARIO -PC.pdf

Ministerio de Educación de la República Dominicana (MINERD) (2016b). Diseño Curricular-Nivel Primario-Segundo Ciclo (4to., 5to. y 6to.). Santo Domingo: Ministerio de Educación de la República Dominicana.

http://www.educando.edu.do/portal/wp-content/uploads/2016/07/NIVEL-PRIMARIO 
$\underline{\text {-SC.pdf }}$

Ministerio de Educación de la República Dominicana (MINERD) (2016c). Diseño Curricular - Nivel Secundario Primer Ciclo(1ero, 2do y 3ero) Versión Preliminar para revisión y retroalimentación. Santo Domingo: Ministerio de Educación de la República Dominicana.

http://www.educando.edu.do/portal/wp-content/uploads/2016/07/NIVEL-SECUNDA RIO-PC.pdf

OECS Education Reform Unit (2006). Primary Social Studies Teachers' Guide Grade K-6. OECS, Castries.

Organization of Eastern Caribbean States (OECS) (2012). Every Learner Succeeds: Education Sector Strategy 2012-2021. OECS, Castries.

http://www.oecs.org/edmu-resources/oecs-education-strategy

Pesoutova, J. (2015). La representación indígena y su papel en la interpretación de los paisajes culturales asociativos actuales. Boletín del Museo del Hombre Dominicano, 46, 195-214.

Pesoutova, J., \& Hofman, C. L. (2016). La contribución indígena a la biografía del paisaje cultural de la República Dominicana: Una revisión preliminar. In J. Ulloa Hung, \& R. Valcárcel Rojas (Eds.), Indígenas e indios en el Caribe: Presencia, legado y estudio (pp. 115-150). Santo Domingo: INTEC.

Priego, J. (1967). Cultura Taína. Compendio Didáctico de La Prehistoria de Quisqueya. Santo Domingo: Secretaría de Estado de Educación.

Reid, B. A. (2009). Myths and Realities of Caribbean History. Tuscaloosa: The University of Alabama Press.

Ricourt, M. (2016). The Dominican Racial Imaginary: Surveying the Landscape of Race and Nation in Hispaniola. New Brunswick, NJ: Rutgers University Press.

Rodríguez López-Vázquez, A., \& Rodríguez López-Abadía, A. (2016). Gonzalo Fernández de Oviedo. Sumario de la historia natural de las Indias. Madrid: Cátedra.

Serna Moreno, J. J. M. (2010). República Dominicana-Identidad y herencias etnoculturales indígenas. Santo Domingo: Archivo General de la Nación.

http://www.agn.gov.do/node/302

Sonnemann, T. F., Ulloa Hung, J., \& Hofman, C. L. (2016). Mapping Indigenous Settlement Topography in the Caribbean Using Drones. Remote Sensing, 8, 791.

https://doi.org/10.3390/rs8100791

Ulloa Hung, J. (2014). Arqueología en la Línea Noroeste de La Española. Paisajes, cerámicas e interacciones. Santo Domingo: Instituto Tecnológico de Santo Domingo.

Ulloa Hung, J., \& Herrera Malatesta, E. (2015). Investigaciones arqueológicas en el norte de la Española, entre viejos esquemas y nuevos datos. Boletín del Museo del Hombre Dominicano, 46, 75-107.

Ulloa Hung, J., \& Valcárcel Rojas, R. (2016). Indígenas e indios en el Caribe: Presencia, legado y estudio. Santo Domingo: INTEC.

Veloz Maggiolo, M. (1997). Prehistoria dominicana para maestros. La Romana: Ediciones Museo Arqueológico Regional Altos de Chavón.

Wilson, S. (2007). The Archaeology of the Caribbean. New York, NY: Cambridge University Press. https://doi.org/10.1017/CBO9780511816505

Wilson, S. (Ed.) (1997). The Indigenous People of the Caribbean. Gainesville: University Press of Florida. 
Submit or recommend next manuscript to SCIRP and we will provide best service for you:

Accepting pre-submission inquiries through Email, Facebook, LinkedIn, Twitter, etc. A wide selection of journals (inclusive of 9 subjects, more than 200 journals)

Providing 24-hour high-quality service

User-friendly online submission system

Fair and swift peer-review system

Efficient typesetting and proofreading procedure

Display of the result of downloads and visits, as well as the number of cited articles Maximum dissemination of your research work

Submit your manuscript at: http://papersubmission.scirp.org/

Or contact ce@scirp.org 